\title{
IMPLEMENTASI HUKUM PUTUSAN MAHKAMAH KONSTITUSI NOMOR 18/PUU-XVII/2019 TERHADAP PROSES EKSEKUSI JAMINAN FIDUSIA
}

\author{
Vinsensius Maku ${ }^{1}$, AM. Tri Anggraini ${ }^{2}$ dan Erna Widjajati ${ }^{3}$ \\ ${ }^{1,2,3}$ Universitas Krisnadwipayana, Jakarta, Indonesia

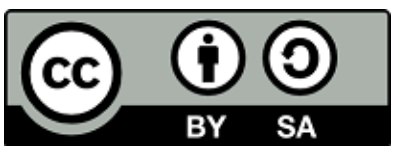 \\ DOI: http://dx.doi.org/10.33603/hermeneutika.v3i2 \\ Diterima: Juli 2020; Direvisi: 31 Agustus 2020; Dipublikasikan: Agustus 2020
}

\begin{abstract}
Abstrak: Kegiatan pinjam meminjam yang terus berkembang di masyarakat memerlukan pengaturan yang jelas dan pasti terutama berkaitan dengan pengembalian dana pinjaman. Salah satu lembaga pemberi pinjaman (Kreditor) adalah lembaga pembiayaan atau leasing. Lembaga Pembiayaan atau leasing mempunyai peran yang sangat penting dalam menggerakan roda perekonomian masyarakat yaitu dengan memberikan fasilitas kredit kepada masyarakat yang ingin memiliki kendaraan baik roda dua maupun roda empat. Penelitian ini melihat Implementasi Hukum Putusan Mahkamah Konstitusi Nomor 18/PUUXVII/2019 Terhadap Proses Eksekusi Jaminan Fidusia. Penelitian ini merupakan penelitian hukum normatif (Studi Kasus). Hasil penelitian menyatakan Putusan Mahkamah Konstitusi (MK) Nomor 18/PUU-XVII/2019 diharapkan dapat menjadi solusi upaya untuk memenuhi rasa keadilan guna mencapai suatu kondisi yang menempatkan kreditur dan debitur dalam posisi yang seimbang
\end{abstract}

Kata Kunci: Eksekusi Fidusa, Mahkamah Konstitusi, Putusan Sidang

\footnotetext{
${ }^{1}$ Vinsensius Maku

Email : vinsen@gmail.com

${ }^{2}$ AM. Tri Anggraini

Email : anggraini@gmail.com

${ }^{3}$ Erna Widjajati

Email : ernawidjajati@gmail.com
} 


\section{PENDAHULUAN}

Kegiatan pinjam meminjam yang terus berkembang di masyarakat memerlukan pengaturan yang jelas dan pasti terutama berkaitan dengan pengembalian dana pinjaman. Untuk melindungi kepentingan baik pemilik dana (kreditor) maupun pengguna/ peminjam dana (debitor), Pemerintah dan Dewan Perwakilan Rakyat (DPR) telah mengeluarkan sebuah Undang-Undang yaitu Undang-Undang Nomor 42 Tahun 1999 tentang Jaminan Fidusia.

Fidusia sendiri sebagai lembaga jaminan kebendaan dapat dibebankan terhadap benda bergerak yang meliputi benda bergerak berwujud dan benda bergerak tidak berwujud. Untuk benda bergerak berwujud seperti barang-barang perniagaan, inventaris, ternak, kapal yang tidak terdaftar, kendaraan bermotor, hasil pertanian, barang-barang rumah tangga dan lain-lain ${ }^{1}$. Sedangkan benda bergerak tidak berwujud seperti piutang atas nama ${ }^{2}$.

Salah satu lembaga pemberi pinjaman (Kreditor) adalah lembaga pembiayaan atau leasing. Lembaga Pembiayaan atau leasing mempunyai peran yang sangat penting dalam menggerakan roda perekonomian masyarakat yaitu dengan memberikan fasilitas kredit kepada masyarakat yang ingin memiliki kendaraan baik roda dua maupun roda empat.

Dalam transaksi pembiayaan konsumen, ada tiga pihak yang terlibat. Pertama, adalah pihak Lembaga Pembiayaan Konsumen (Pemberi dana Pembiayaan atau Kreditor). Kedua, pihak konsumen (Penerima dana pembiayaan atau debitor), dan ketiga pihak supplier

\footnotetext{
1 Mariam Darus Badrulzaman, Bab-Bab tentang Credietverband Gadai \& Fidusia, Bandung: Citra Aditya Bakti, 1991, hal. 102

2 Sri Soedewi, Bebarapa Masalah Pelaksanaan Lembaga Jaminan Khususnya Fidusia Di Dalam Praktik Dan Pelaksanaannya di Indonesia, Bandung : Fakultas Hukum Universitas Gajah Mada, 1977, hal.32
}

(Penjual atau Penyedia Barang). Adapun hubungan yang terjadi antara pihak kreditur dengan pihak debitur adalah suatu hubungan kontraktual dalam hal pembiayaan konsumen. Pada sistem pembiayaan konsumen ini pihak Lembaga Pembiayaan Konsumen memberikan pembiayaan berupa pinjaman dana untuk pembelian suatu barang. Pihak konsumen selanjutnya akan menerima fasilitas dana untuk pembelian barang tertentu dan membayar hutangnya secara berkala atau angsuran kepada Lembaga Pembiayaan Konsumen. Pihak penjual atau supplier menyediakan barang yang dibayar lunas oleh Lembaga Pembiayaan Konsumen. ${ }^{3}$

Undang-Undang Nomor 42 Tahun 1999 tentang Jaminan Fidusia telah memberikan aturan mengenai pelaksanaan eksekusi atas objek Jaminan Fidusia, namun faktanya di lapangan pelaksanaan eksekusi yang dilakukan oleh lembaga pembiayaan tidak mematuhi aturan perundang-undangan yang berlaku.

Dalam hal kreditor (penerima fidusia) mengambil pelunasan hutang atas tagihan dalam hal debitur wanprestasi, dapat menggunakan beberapa cara yaitu: (1) Melalui gugatan biasa (2) Mendasarkan kepada grosse sertifikat jaminan fidusia, (3) Melalui parate eksekusi ${ }^{4}$.

Walaupun tidak secara tegas dijelaskan, tetapi sesuai dengan pengertian parate eksekusi yang selama ini dianut, maka kreditur dapat melaksanakan parate eksekusi berdasarkan Pasal 15 ayat (3) Undang-Undang Jaminan Fidusia, tanpa harus mengikuti prosedur hukum acara, tanpa perlu fiat eksekusi dari pengadilan, tanpa memerlukan penyitaan dan tanpa perantaraan juru sita. Akan tetapi untuk melindungi kepentingan pemberi jaminan

\footnotetext{
3 Muhammad Chidir, Pengertian-pengertian Elementer Hukum Perjanjian Perdata, Bandung: Mandar Maju, 1993, hal. 166.

4 Tan Kamello, Hukum Jaminan Fidusia Suatu Kebutuhan Yang Didambakan, Bandung: Alumni, 2004, hal. 238
} 
fidusia, pelaksanaan eksekusi harus dilaksanakan di depan umum melalui juru lelang, kecuali untuk benda-benda tertentu, penjualannya dapat dilakukan menurut cara yang disebutkan dalam Pasal 31 Undang-Undang Nomor 42 Tahun 1999 tentang Jaminan Fidusia.

$$
\text { Jaminan Fidusia memberikan }
$$

kedudukan yang istimewa terhadap kreditor dalam melaksanakan haknya manakala debitur wanprestasi atau bahkan dinyatakan pailit oleh Pengadilan. Secara limitatif Peraturan Otoritas Jasa Keuangan Republik Indonesia Nomor 35/POJK.05/2018 Tentang Penyelenggaraan Usaha Pembiayaan ini membatasi yang dapat dilakukan jika debitur tidak dapat memenuhi kewajibannya yaitu:

$$
\text { Penjualan agunan melalui }
$$

pelelangan umum (Pelelangan umum mengikuti Peraturan Menteri Keuangan Nomor 27/PMK.06/2016 Tentang Petunjuk Pelaksanaan Lelang) pada pokoknya permenkeu tersebut memerintahkan sebelum lelang dilakukan agar diumumkan di surat kabar paling lambat enam hari sebelumnya;

Penjualan agunan di bawah tangan dilakukan berdasarkan kesepakatan para pihak, pada pokoknya Peraturan Otoritas Jasa Keuangan Republik Indonesia Nomor 35/POJK.05/2018

Tentang

Penyelenggaraan Usaha Pembiayaan menentukan untuk penjualan agunan di bawah tangan ini dapat dilakukan setelah lewat waktu 1(satu) bulan sejak pemberitahuan tertulis oleh kreditur, selain itu kreditur wajib memberitahu melalui 2(dua) surat kabar di daerah tersebut dan apabila terhadap penjualan melalui pelelangan atau penjualan di bawah tangan terdapat kelebihan maka Kreditur wajib untuk mengembalikan kelebihan tersebut kepada debitur;

Bahwa sertifikat jaminan fidusia memiliki kekuatan eksekutorial yang sama dengan putusan pengadilan yang berkekuatan hukum tetap, namun apabila debitur tidak mentaati untuk menyerahkan objek jaminan fidusia kepada kreditor secara sukarela, maka selama objek jaminan fidusia tersebut masih dalam penguasaan debitor (tidak digadai/dijual/dialihkan kepada pihak lain) maka debitor terhindar dari sanksi hukuman pidana sebagaimana diatur pada Pasal 36 Undang Undang Nomor 42 Tahun 1999 Tentang Jaminan Fidusia;

Namun demikian Penerima Fidusia (Kreditor) seringkali memaksakan kehendak dengan menggunakan pihak ketiga (debt collector) atau juru tagih untuk mengambil secara paksa dan melawan hukum seperti yang dialami oleh salah satu debitor yang menjadi Pemohon dalam perkara pengujian Undang-Undang Nomor 42 Tahun 1999 Pasal 15 ayat (2) dan ayat (3) terhadap Undang-Undang Dasar 1945 yang telah diputuskan oleh Mahkamah Konstitusi dengan nomor: 18/PUU-XVII/2019.

Berdasarkan paparan di atas, maka penelitian ini dengan judul, Implementasi Hukum Putusan Mahkamah Konstitusi Nomor 18/PUU-XVII/2019 Terhadap Proses Eksekusi Jaminan Fidusia.

\section{Pembahasaan}

Fidusia atau lengkapnya "Fiduciaire Eigendomsoverdracht" sering disebut sebagai Jaminan Hak Milik Secara Kepercayaan, merupakan suatu bentuk jaminan atas benda-benda bergerak disamping gadai di mana dasar hukumnya yurisprudensi. Pada fidusia, berbeda dari gadai, yang diserahkan sebagai jaminan kepada kreditur adalah hak milik sedang barangnya tetap dikuasai oleh debitur, sehingga yang terjadi adalah penyerahan secara constitutum possessorium.

Menurut ketentuan Pasal 1 butir 1 UUJF, menyatakan bahwa: "Fidusia adalah pengalihan hak kepemilikan suatu benda atas dasar kepercayaan dengan ketentuan bahwa benda yang hak kepemilikannya dialihkan tersebut tetap dalam penguasaan pemilik benda". Berdasarkan perumusan pengertian fidusia 
tersebut di atas dapat diketahui unsurunsur dari suatu Jaminan Fidusia, yaitu:

1) Pengalihan hak kepemilikan suatu benda;

2) Dilakukan atas dasar kepercayaan;

3) Kebendaanya tetap dalam penguasaan pemilik benda.

Dengan demikian, dalam fidusia telah terjadi penyerahan dan pemindahan dalam kepemilikan atas suatu benda yang diajukan atas dasar fiduciary atau kepercayaan dengan syarat bahwa benda yang hak kepemilikannya tersebut diserahkan dan dipindahkan kepada lembaga pembiayaan tetap dalam penguasaan pemilik benda (konsumen). Dalam hal ini yang diserahkan dan dipindahkan itu dari pemilinya kepada kreditur (lembaga pembiayaan) adalah hak kepemilikan atas suatu benda yang dijadikan sebagai jaminan, sehingga hak kepemilikan secara yuridis atas benda yang dijaminkan beralih kepada kreditur (lembaga pembiayaan), sementara hak kepemilikan secara ekonomis atas benda yang dijaminkan tersebut masih tetap berada dalam penguasaan pemiliknya. Dalam hal inilah kepercayaan sangat diperlukan dalam hal lembaga pembiayaan percaya bahwa walaupun barang jaminan berada dalam penguasaan debitur namun pelunasan atas utang yang telah diberikan oleh kreditur tetap terjamin.

\section{METODE PENELITIAN}

Penelitian ini merupakan penelitian studi kasus. Tempat penelitian yang dilakukan yaitu pada di Pengadilan Negeri Jakarta Utara yang beralamat di Jalan Jl. Medan Merdeka Barat No.6 RT2/RW3, Gambir, Kecamatan Gambir, Kota. Jakarta Pusat, Daerah Khusus Ibukota Jakarta 10110. Metode yang digunakan pendekatan yuridis normatif. Pendekatan yuridis (hukum dilihat sebagai norma atau das sollen), karena dalam membahas permasalahan penelitian ini menggunakan bahan-bahan hukum. ${ }^{5}$ Setelah data yang dibutuhkan terkumpul kemudian menuju kepada identifikasi masalah yang pada akhirnya menuju pada penyelesaian masalah. ${ }^{6}$ penelitian hukum normatif berfokus pada peraturan-peraturan tertulis berupa literatur-literatur kepustakaan baik berupa peraturan perundang-undangan, norma-norma dan kaedah-kaedah yang berhubungan dengan pokok permasalahan. Pada masing-masing asas hukum dibahas substansinya, sturuktur hukum dan budaya hukum. Untuk menjawab permasalahan dan mencapai tujuan dari penelitian ini, peneliti menggunakan jenis penelitian normatif dengan melihat hukum dalam konteks normatifnya. Studi dalam hukum normatif lebih berfokus pada studi kepustakaan (Library Research).

\section{HASIL DAN PEMBAHASAN}

Terjadi tindakan sewenang-wenang yang dilakukan Penerima Fidusia (PT. Astra Sedaya Finance) dilakukan dengan menyewa jasa debt collector, untuk mengambil alih barang yang dikuasai Pemohon (debitor) tanpa melalui prosedur hukum yang benar. Ada beberapa momentum tindakan paksa, tanpa menunjukkan bukti dan dokumen resmi, tanpa kewenangan, dengan menyerang diri pribadi, kehormatan, harkat dan martabat, serta mengancam membunuh Para Pemohon.

Pemohon I adalah debitor (Pemberi Fidusia)yang berdasarkan perjanjian kredit nomor 01100191001653145 dimana PT. Astra Sedaya Finance memberikan fasilitas pembiayaan kepada Pemohon I dalam bentuk penyediaan dana untuk pembelian 1 (satu) unit kendaraan Merk Toyota Type Alphard V Model 2.4 A/T Tahun 2004, warna abu-abu muda metalik,

5 Ahmad Tanzeh, Pengantar Metode Penelitian, Yogyakarta: Teras, 2009, hlm. 14.

6 Bambang Waluyo, Penelitian Hukum Dalam Praktek, Jakarta: Sinar Grafika, 2002, hlm. 16. 
No. Rangka ANH100081947, No. Mesin 2AZ1570674. Sesuai perjanjian pembiayaan multiguna tersebut, maka Pemohon I (debitor) memiliki kewajiban pembayaran hutang kepada PT. Astra Sedaya Finance (Kreditor) sebesar Rp 222.696.000,- (dua ratus dua puluh dua juta enam ratus sembilan puluh enam ribu rupiah) yang akan dibayar secara angsuran selama 35 (tiga puluh lima) bulan, mulai dari 18 November 2016.

Alasan mendasar dilakukannya eksekusi atas benda jaminan fidusia Oleh Penerima Fidusia adalah adanya Sertifikat Fidusia yang dikeluarkan oleh kantor pendaftaran fidusia sebagaimana diatur dalam Pasal 14 yang berbunyi sebagai berikut:

1) Kantor Pendaftaran Fidusia menerbitkan dan menyerahkan kepada Penerima Fidusia Sertifikat Jaminan Fidusia pada tanggal yang sama dengan tanggal penerimaan permohonan pendaftaran.

2) Sertifikat Jaminan Fidusia yang merupakan salinan Buku Daftar Fidusia memuat catatan tentang halhal sebagaimana dimaksud dalam Pasal 13 ayat (2).

3) Jaminan Fidusia lahir pada tanggal yang sama dengan tanggal dicatatnya Jaminan Fidusia dalam Buku Daftar Fidusia.

Pada prakteknya pihak lembaga pembiayaan non bank dalam melakukan penagihan atas angsuran yang macet bekerjasama dengan pihak ketiga yaitu debt collector external untuk melakukan eksekusi barang jaminan kredit yang bermasalah yang tidak dapat ditangani collector regular. Debt collector external bukanlah berstatus sebagai karyawan lembaga pembiayaan, tetapi pihak diluar perusahaan yang diberi kuasa untuk bekerja atas nama lembaga pembiayaan untuk menangani konsumen yang mengalami gagal bayar atau kredit macet. Kebijakan untuk melibatkan pihak ketiga dalam menangani konsumen-konsumen gagal bayar dilakukan lembaga pembiayaan setelah prosedur dan upaya yang dilakukan pihak kolektor reguler dalam kurun waktu tertentu tidak menunjukkan hasil. Ketidakberhasilan ini dapat dikarenakan faktor kurang kerasnya usaha yang dilakukan kolektor reguler, dapat juga karena tingkat kesulitan yang tinggi dari permasalah yang ada pada konsmumen- konsumen gagal bayar tersebut, sehingga lembaga pembiayaan tidak mau mengambil resiko penyelesaian kredit bermasalah tersebut.

Pada masalah tersebut maka Pemohon dalam permohonan pengujian Undang-Undang terhadap UUD 1945 mengemukakan bahwa hak konstitusionalnya telah dirugikan dan dilanggar oleh berlakunya UU Jaminan Fidusia yang pada intinya sebagai berikut: Bahwa dengan berlakunya pasal 15 ayat (2) dan ayat (3) yang dimohonkan Para Pemohon, senyatanya telah merugikan hak konstitusional Para Pemohon.

Bahwa berkaitan dengan pelaksanaan eksekusi atas benda jaminan fidusia yang didasarkan atas ketentuan Pasal 15 ayat (2) dan ayat (3), majelis hakim Mahkamah Konstitusi mempunyai pertimbangan dan Putusan Mahkamah Konstitusi (MK) Nomor 18/PUUXVII/2019 menyatakan bahwa Pasal 15 ayat (2) dan (3) serta Penjelasan Pasal 15 ayat (2) Undang-Undang Nomor 42 Tahun 1999 tentang Jaminan Fidusia berlaku secara inkonstitusional bersyarat (conditionally unconstitusional)

\section{KESIMPULAN \& SARAN}

(MK) Nomor 18/PUU-XVII/2019 menyatakan bahwa Pasal 15 ayat (2) dan (3) serta Penjelasan Pasal 15 ayat (2) Undang-Undang Nomor 42 Tahun 1999 tentang Jaminan Fidusia berlaku secara inkonstitusional bersyarat (conditionally unconstitusional). Artinya, ketentuan tersebut harus dianggap bertentangan dengan UUD 1945 (inkonstitusional) jika syarat yang ditetapkan Mahkamah Konstitusi tidak dipenuhi sesuai dengan 
amar putusan. Pelaksanaan eksekusi benda jaminan fidusia sebelum adanya Putusan Mahkamah Konstitusi (MK) Nomor 18/PUU-XVII/2019 sering terjadi adanya perbedaan interpretasi bagaimana memaknai kalimat "kekuatan eksekutorial" dan "sama dengan putusan pengadilan" yang diatur dalam pasal tersebut. Berdasarkan putusan Mahkamah Konstitusi tersebut, dapat disimpulkan bahwa eksekusi jaminan fidusia dilakukan saat adanya kesepakatan mengenai cidera janji dan kerelaan debitur untuk menyerahkan benda yang menjadi objek fidusia. Apabila tidak terdapat kesepakatan mengenai cidera janji dan debitur tidak menyerahkan objek jaminan secara sukarela, maka prosedur eksekusi jaminan fidusia dilakukan sama dengan eksekusi putusan pengadilan yang telah berkekuatan hukum tetap. Selain itu, cidera janji juga tidak dapat ditentukan secara sepihak. Harus ada kesepakatan mengenai cidera janji/wanprestasi yang ditentukan oleh kedua belah pihak atau atas dasar upaya hukum (gugatan) yang menyatakan bahwa salah satu pihak telah melakukan wanprestasi.

Putusan Mahkamah Konstitusi (MK) Nomor 18/PUU-XVII/2019 diharapkan dapat menjadi solusi upaya untuk memenuhi rasa keadilan guna mencapai suatu kondisi yang menempatkan kreditur dan debitur dalam posisi yang seimbang serta mampu memberikan perlindungan hukum kepada debitur selaku pemberi fidusia dan juga perlindungan hukum kepada kreditur selaku penerima fidusia.

\section{DAFTAR PUSTAKA}

Bachtiar Sibarani, Haircut atau Pareta Eksekusi, Jurnal Hukum Bisnis, 2001, hal. 6

C. S. T. Kansil, Pokok-pokok Pengetahuan Hukum Dagang Indonesia, Jakarta: Sinar Grafika, 1992, hal. 194.
C.AE Uniken Venema Zwalve, Common Law \& Civil Law, W.E.J Tjeenk Willink, Deventer, 2000, hal. 25

Chamidah, Dina, Sonny Kristianto, Sunaryo, Otto Fajarianto, Andi Ahmad, Yuli Ani Setyo Dewi, Edi Sambodja, Diah Ambarumi Munawaroh, Nurlaeli Fitriah, and Prita Indriawati. 2019. "Feasibility of Based Augmented Reality Devices Discovery Learning on Students Learning Outcomes in Morphology of Wijaya Kusuma Flower (Epiphyllum Anguliger)." in Journal of Physics: Conference Series.

Cst Kansil, Christine, S.T Kansil, Engelien $\mathrm{R}$, Palandeng dan Godlieb N Mamahit, Kamus Istilah Hukum, Jakarta, 2009, Hlm. 385.

Dominikus Rato, Filsafat Hukum: Mencari, dan Memahami Hukum, Laksbang Pressindo, Yogyakarta, 2009 hal.59

Gunawan Widjaja dan Ahmad Yani, Jaminan Fidusia, Jakarta: PT. Raja Grafindo Persada, 2007, hal. 133

Henry Campbell Black, Black' s Law D ict io nar y, Sixth Edition, Minn: West Publishing Co., St. Paul, 1990, p. 625

Mochammad Dja'is, Hukum Eksekusi Sebagai Wacana Baru DIbidang Hukum, disampaikan dalam rangka Dies Natalis ke-43, Semarang: Undip, 2000, hal. 7.

Peraturan Menteri Keuangan Nomor 27/PMK.06/2016 tentang Petunjuk Pelaksanaan Lelang.

Peraturan Menteri Keuangan Republik Indonesia No.130/PMK.010/2012 tentang Pendaftaran Jaminan Fidusia Bagi Perusahaan Pembiayaan Yang Melakukan Pembiayaan Konsumen Untuk Kendaraan Bermotor Dengan Pembebanan Jaminan Fidusia.

Peraturan Otoritas Jasa Keuangan Nomor: 29/POJK.05/2014 tentang 
Penyelenggaraan Usaha

Perusahaan Pembiayaan.

Putusan Mahkamah Konstitusi Nomor: 18/PUU-XVII/2019 tentang Pengujian Undang-Undang Nomor 42 Tahun 1999 terhadap UUD 1945.

R. Setiawan, Pokok-Pokok Hukum Perikatan, Bandung: Bina Cipta, 1979, hal. 49.

Salim H. S. Perkembangan Hukum Jaminan Indonesia, Jakarta: Raja Grafindo Persada, 2004, hal. 60.

Soerjono Soekanto dan Sri Mamudji. Penelitian Hukum Normarif, Raja Grafindo Persada, Jakarta: 1995, hlm. 13-14.

Sri Soedewi, Bebarapa Masalah Pelaksanaan Lembaga Jaminan Khususnya Fidusia Di Dalam Praktik Dan Pelaksanaannya di
Indonesia, Bandung: Fakultas Hukum Universitas Gajah Mada, 1977, hal.32

Undang-Undang Nomor 19 Tahun 1997 tentang Penagihan Pajak Dengan Surat Paksa sebagaimana telah diubah dengan Undang-Undang Nomor 19 Tahun 2000.

Undang-Undang Nomor 42 Tahun 1999 Tentang Jaminan Fidusia.

Widyarto, Setyawan, I. Nyoman Suryasa, Otto Fajarianto, Khairul Annuar Bin Abdullah, Mohd Shafry Mohd Rahim, Gigih Priyandoko, and Gilang Anggit Budaya. 2017. "Wood Texture Detection with Conjugate Gradient Neural Network Algorithm." in International Conference on Electrical Engineering, Computer Science and Informatics (EECSI). 